\title{
Interactive Effect of Copper and Its Mineral Collectors on Soil Microbial Activity-A Microcalorimetric Analysis
}

\author{
Prudence Bararunyeretse*, Howard 0. Beckford, Hongbing Ji* \\ Beijing Key Laboratory of Resource-Oriented Treatment of Industrial Pollution, School of Energy and \\ Environmental Engineering, University of Science and Technology Beijing, Beijing, China \\ Email: ‘ji.hongbing@hotmail.com, *prudencebara@gmail.com
}

How to cite this paper: Bararunyeretse, P., Beckford, H.O. and Ji, H.B. (2019) Interactive Effect of Copper and Its Mineral Collectors on Soil Microbial Activity-A Microcalorimetric Analysis. Open Journal of Soil Science, 9, 47-64.

https://doi.org/10.4236/ojss.2019.93003

Received: February 22, 2019

Accepted: March 18, 2019

Published: March 21, 2019

Copyright $\odot 2019$ by author(s) and Scientific Research Publishing Inc. This work is licensed under the Creative Commons Attribution International License (CC BY 4.0).

http://creativecommons.org/licenses/by/4.0/

\begin{abstract}
Discharge of metals and their mineral flotation collectors into the soil environment causes severe ecological and health impacts, which is still not fully understood. This is of great concern, particularly with regards to their effect on the soil microorganisms whose functions determine not only the soil quality and function but also influence the air and water quality. This study aimed to analyze and compare, microcalorimetrically, the single chemical toxic effect with the combined effect of copper $(\mathrm{Cu})$ and two of its main flotation collectors, potassium amyl xanthate (PAX) and sodium isoamyl xanthate (SIAX), on soil microbial community. All chemicals, individually and as a binary mixture of copper and each of its flotation collectors, exhibited a significant dose-effect relationship, and the highest and lowest microbial activity inhibition being associated with SIAX and $\mathrm{Cu}$, respectively (e.g. IC 50 of 447.5, 158.3 and $83.9 \mu \mathrm{g} \cdot \mathrm{g}^{-1}$ soil for copper, PAX and SIAX, respectively). For all cases, the microbial activity was more affected by the mixture than by the individual mixture components. Increasing the xanthates dose (from 25 to $100 \mu \mathrm{g} \cdot \mathrm{g}^{-1}$ soil) in the mixture with a copper dose of $200 \mu \mathrm{g} \cdot \mathrm{g}^{-1}$ soil led to the increase of the microbial activity inhibition rate, from $23.08 \%$ to $53.85 \%$ in case of PAX and from $26.92 \%$ to $57.69 \%$ in case of SIAX). Similarly, the toxicity level of the mixture of equitoxic components doses increased with the increased mixture doses. Since the observed activity level can be attributed to the surviving microbes, capable of adapting to both chemical and their mixture, a genetically based analysis should be conducted to allow identifying and characterizing the potentially resistant strains that can be useful for the remediation of the pollution by copper and xanthates and for the sustainability of copper mining and flotation, and for all soil, water, and air quality and function interest.
\end{abstract}




\section{Keywords}

Copper, Mineral Collectors, Soil Microbial Activity, Single Toxicity, Mixture Toxicity, Microcalorimetry

\section{Introduction}

Soil microorganisms constitute the most soil active constituent, mediating almost all processes within the soil [1], including soil formation and stability, soil organic matter decomposition, soil chemicals and nutrients cycling, soil decontamination and detoxification, as well as soil water and air quality and quantity regulation (e.g. carbon sequestration and green gas regulation) [2] [3]. Unfortunately, they are highly sensitive to pollution [4] while their living environment, the soil ecosystem, is the main destination of various pollutants, including heavy metals and flotation reagents from mining and ores processing. Understanding the interaction between soil microbes and these pollutants, including copper, and the mineral flotation collectors such as xanthates remains of great scientific interest.

Copper $(\mathrm{Cu})$ is widely distributed in the environment, ranking $26^{\text {th }}$ in abundance in the lithosphere and is one of the most extensively mined and processed metals worldwide [5] [6]. Its main anthropogenic releasing sources into the environment include $\mathrm{Cu}$ mining and $\mathrm{Cu}$ processing, wastes disposal, and various agricultural and industrial applications. It was estimated that more than $90 \%$ of $\mathrm{Cu}$ emitted from all sources is primarily released to land, including agricultural soil [5]. For the environmental protection and soil quality and function issues, $\mathrm{Cu}$ permissible level was fixed to $63 \mathrm{mg} \cdot \mathrm{kg}^{-1}$ soil for the agricultural and residential land and $91 \mathrm{mg} \cdot \mathrm{kg}^{-1}$ soil for the commercial and industrial land areas in Canada [7], 50 to $100 \mathrm{mg} \cdot \mathrm{kg}^{-1}$ soil for the agricultural soil in China [8]. However, higher copper soil contamination, largely exceeding the environmental standards, has been reported in both urban and rural areas and $\mathrm{Cu}$ concentration remains higher even far from its emitting sources [7] [8] [9].

On the other hand, flotation reagents constitute a non-replaceable part of mineral beneficiation through flotation, a process of extracting valuable minerals from the rest of the gangue [10]. Xanthates $\left(\mathrm{ROCS}_{2}^{-} \mathrm{Na}^{+} / \mathrm{K}^{+}\right.$) which are cost-effective and highly mineral selective are by far the largest volume collectors used for the sulfide minerals extraction and concentration [11] [12]. They are organic chemicals comprising of the non-polar group (water repellent hydrocarbon radical), and a polar group $\left(\mathrm{S}=\mathrm{C}-\mathrm{S}^{-}\right)$that can react with water and can interact with the polar surface of minerals by replacing the $\mathrm{Na}$ and $\mathrm{K}$ ions and repelling the non-polar group. This creates the hydrophobicity of the mineral's surface on which the flotation process relies [13]. Potassium amyl xanthate (PAX), and sodium isoamyl xanthate (SIAX) are among the commonly used as copper flotation collectors. To meet the growing demand in metals, billions of tons ores are 
annually processed through flotation, consuming a huge amount of flotation reagents, 10 to more than $300 \mathrm{~g}$ of xanthates per ton of ore [10] [13]. Due to the gradual depletion of high-grade ore reserves over time, exploiting low-grade and complex ores [14] [15] necessitates an increase in the amount of ore processed and higher xanthates use. The flotation collector's growth rate consumption has been estimated to $2 \%$ - 3\% per year [12]. Unfortunately, only a half of the total input quantity is effectively consumed [11], the remaining part, residues, and the unrecovered metals being released into the environment, generally without treatment [12]. Similar to copper, xanthates can be released into the environment from other various sources, including from their use as reactants or additives in the pesticides, herbicides, cellulose, rubber, and pharmaceuticals industries. They may also reach the soil environment from manufacturing, transportation (accidental spills) and disposal [16]. Tailings that constitute the main mining and ore processing wastes discharged sites are still generally limited in preventing pollution and present a high risk for pollution [17] of soil, water, and air and for both proximal and distant environment. They constitute a source of pollution by heavy metals, metals oxidation products, and flotation reagents and their degradation associated products. These pollutants can reach and contaminate the surface and ground waters by leaching [17] and infiltration. They are also dispersed to long distances by run-off and erosion, volatilization and transport by wind/air, plant uptake [18] and transfer via the food chain [19]. Such a spread of pollutants can be magnified by tailing dam failures that constitute the most frequently reported mining- and ore processing-related environmental incidents worldwide [20] [21]. During 2000-2009, North America, Asia, and the European continents were the most affected regions by such incidents [20] that generally occur in active mines (more than $90 \%$ of the cases) [21].

With regard to their toxicity, both copper and xanthates are known for their adversity for the living system. However, the sensitivity of different organisms to pollutants depends on chemical species [3] and the unique action of each element [22] Copper can cause the generation of hydroxyl free radicals, including hydrogen peroxide and superoxide, which can provoke cellular damage and cells death [23]. $\mathrm{Cu}$ interacts with and deteriorates nucleic acids, alter enzymes active sites, and oxidize the cell membrane components [6] [24]. Regarding xanthates, their ecotoxicity is still less understood [16]. Human and animals exposure can cause oral and dermal toxicity, eye irritation, damage of the spleen, liver, kidneys, respiratory system, peripheral and central nervous system [16], as well as the loss or inactivation of enzymes [25]. Xanthates were also found extremely toxic to aquatic organisms [26]. Therefore, zero level exposure to xanthates is recommended for humans [25] and xanthates concentration in water bodies should not exceed $0.05 \mathrm{ng} / \mathrm{mL}$ [11]. In this regards, the effects of xanthates on soil microorganisms should also attract more scientific attention, particularly for their interactive effects with metals. The existing related risk assessment and management efforts have mostly focused on individual elements and cannot 
provide a full knowledge on the microbial state in the presence of a complex of metal and xanthates as it is in the context of mining, ores processing and applications of these elements.

Exposure to structurally and toxicologically different substances can lead to different toxicological types of reactions, including additivity (usually upon dose addition), synergism (greater than additive action) or antagonism (less than additive toxicity) [27]. Models have been developed to predict the effect of the combined chemical based on the individual toxicity data, the commonly used being the concentration addition (CA) and the independent action (IA). The principle of $\mathrm{CA}$ is that the mixture components have a common site of action, meaning that the replacement of a chemical component by an equitoxic amount of another results in the same effect [28]. This model has relevant applications in pharmacology and is largely considered as a general concept for the pollutants joint action analysis although it has not gained much attention in the aquatic toxicology [28]. Regarding the IA model, it is based on the idea that the mixture components act independently in a statistical sense [29]. Toxicologically, IA means that compounds having different molecular acceptor sites may act on different physiological systems [30]. Considering the affinity and interaction between metals and their flotation collectors that can impact on their bioavailability and interaction with the exposed organisms, and also considering the instability of xanthates that depends on various factors, including the moisture, temperature, and $\mathrm{pH}$ conditions that results in the generation of various decomposition products [31], these two prediction models (CA and IA) may not be appropriately applied to the assessment of the mixture toxicity of metals and xanthates. It is known that metals are the most active in their ionic form (e.g. $\mathrm{Cu}^{2+}$ ) that can interact with xanthates to yield complex compound(s) whose toxicological properties can differ from those of the individual chemicals. The observed effect level would, therefore, be attributed to the presence of copper, xanthates and the newly formed compounds while the surviving organisms that maintain a certain level of activity must, therefore, be capable of adapting to all of those elements in presence. In this framework, the main objective of this study is to analyze, microcalorimetrically, the interactive effect of $\mathrm{Cu}$ and its mineral collectors, $\mathrm{PAX}\left(\mathrm{C}_{6} \mathrm{H}_{12} \mathrm{OS}_{2} \mathrm{~K}\right)$ and SIAX $\left(\mathrm{C}_{6} \mathrm{H}_{11} \mathrm{OS}_{2} \mathrm{Na}\right)$, to the soil microbial activity. Analysis of the mixture toxicity requires the application of a sensitive, rapid, inexpensive, accurate and reliable ecotoxicity test, such as the microcalorimetry that can monitor the heat flow of the microbial metabolic activity as it is for any other biological process [32] [33] [34]. This passive method is a non-disturbing and non-destructive process that allows continuous and real-time monitoring of the activities of living systems in situ [34]. The results of this study will increase the understanding of the soil microbial community activity under the exposure to copper and xanthates and within a copper mining environment. They can serve as a basis for the related risk management and remediation of the pollution by copper and xanthates. 


\section{Material and Methods}

\subsection{Soil Collection and Analysis}

Soil from farmland, in Beijing $\left(39^{\circ} 59^{\prime}-116^{\circ} 21^{\prime}\right)$, was selected for this study. After the removal of the uppermost soil layer, soils samples were collected at a depth of $5-15 \mathrm{~cm}$ ground surface soil, the most populated soil layer by microorganisms [35]. It was then transported in sterile polyethylene bags to the laboratory where it was air-dried at room temperature, homogenized, and sieved (mesh size $2 \times 2 \mathrm{~mm}$ ) for the removal of the large particles. The physicochemical characteristics of this soil were previously analyzed [36] as follows: $\mathrm{pH}, 7.26 ; \mathrm{Zn}$, $3.3 \mathrm{mg} \cdot \mathrm{kg}^{-1}$; Fe, $16.5 \mathrm{mg} \cdot \mathrm{kg}^{-1}$; Total organic matter, $17.1 \mathrm{~g} \cdot \mathrm{kg}^{-1}$; total $\mathrm{N}, 76.2$ $\mathrm{mg} \cdot \mathrm{kg}^{-1}$; P, $78.9 \mathrm{mg} \cdot \mathrm{kg}^{-1}$; and $\mathrm{K}, 144.5 \mathrm{mg} \cdot \mathrm{kg}^{-1}$. Samples were collected in July 2016 and stored in sterile polyethylene bags and kept at $4^{\circ} \mathrm{C}$.

\subsection{Reagents}

$\mathrm{Cu}$ was used as $\mathrm{CuSO}_{4} \cdot 5 \mathrm{H}_{2} \mathrm{O}$ compound. Copper sulfate $\left(\mathrm{CuSO}_{4}\right)$ is one of the most used copper compounds and one of the most contributors to environmental pollution by this element. Xanthates, PAX and SIAX, were provided in the solid and analytical form from Beijing General Research Institute of Mining and Metallurgy. Both copper and collectors stock solutions were prepared using distilled water and were kept at $4^{\circ} \mathrm{C}$ during the experimental time.

\subsection{Experimental Procedure}

\subsubsection{Samples Treatment}

The soil samples treatment was performed as follows: 1) for the individual toxicity analysis, the soil samples were amended with different doses of $\mathrm{Cu}(100,200$, 300,400 , and $600 \mu \mathrm{g} \cdot \mathrm{g}^{-1}$ soil) and xanthates $\left(25,50,100\right.$, and $200 \mu \mathrm{g} \cdot \mathrm{g}^{-1}$ soil). The obtained results allowed determining different inhibitory concentrations, IC 12.5, IC 25 and IC 50, corresponding to the chemical concentrations that can inhibit $12.5 \%, 25 \%$ and $50 \%$ of the microbial growth, respectively. Comparison between chemicals was made based on the inhibitory concentrations. 2) to analyze the level of the mixture toxicity, soil samples were treated with the mixture of the equitoxic doses of $\mathrm{Cu}$ and xanthates, and 3) to allow understanding the effect of the variation of xanthates concentration in the mixture, the soil samples were spiked with an increasing dose of xanthates $\left(25,50\right.$, and $100 \mu \mathrm{g} \cdot \mathrm{g}^{-1}$ soil) and a fixed dose of $\mathrm{Cu}\left(200 \mu \mathrm{g} \cdot \mathrm{g}^{-1}\right.$ soil $)$.

\subsubsection{Microcalorimetric Measurement}

The measurement of soil microbial activity in the absence of pollutants (control sample) and under the exposure to the individual and mixture of copper and each of the studied flotation collectors were conducted using a multi-channel thermal activity monitor, TAM III (TA Instruments, Delware, USA). Soil samples were firstly conditioned at the temperature of microcalorimetric measurement $\left(28^{\circ} \mathrm{C}\right)$. The experiments were conducted in cleaned, sterilized, and her- 
metically sealed $4-\mathrm{mL}$ steel ampoules containing $1 \mathrm{~g}$ of soil samples. To stimulate the soil microbial growth, all samples were supplemented with $0.2 \mathrm{~mL}$ of a nutrient solution made of $5.0 \mathrm{mg}$ glucose and $5.0 \mathrm{mg}$ ammonium sulfate that can provide enough nutrients (i.e. C, N, S) for the microbial growth [37]. The soil microbial metabolic activity was continuously detected and monitored over time (up to $48 \mathrm{~h}$ ) at a constant temperature of $28^{\circ} \mathrm{C}$.

\subsection{Data Analysis}

Data analysis was conducted using the Origin 8.5 (OriginLab, MA, USA) software, Excel, and Spss Statistics 17.0 software packages. Comparison between results was performed through the Pearson correlation coefficient analysis, with a statistical significance of $P<0.05$ or $P<0.01$. All treated samples were compared to the control sample. The power-time curves allowed obtaining the peak-time $\left(T_{\text {peak }}\right)$ values of the microbial growth and the corresponding peak-power $\left(P_{\text {peak }}\right)$ values. The microbial growth rate constant $(k)$ was calculated through linear fitting equation using the semilogarithmic conversion of the heat flow rate data [36] [37] [38] (Equation (1)) while the inhibitory ratio ( $I$, in \%) was calculated on the basis of $K$ as follows (Equation (2)) :

$$
\begin{gathered}
P_{t}=P_{0} \exp (k t) \text { or } \ln P_{t}=\mathrm{n} P_{0}+k_{t} \\
I(\%)=\frac{K_{0}-K_{c}}{K_{0}} \times 100
\end{gathered}
$$

where $P_{0}$ and $P_{t}$ are, respectively, the heat output at time 0 and time $t, I(\%)$ is the inhibitory ratio and $K_{0}$ and $K_{c}$ are the growth rate constant of the control and the growth rate constant of soil microbes under $c$ dose of toxicant, respectively. $K$ and $I$ are the most used parameters for a quantitative evaluation of the microbial response to a given stressful condition [37] [39]. On this basis, the mixture inhibitory ratio was compared to that of the individuals' mixture components to determine whether the exposure to the mixture could be more harmful or not with respect to the individual effects of the components of the mixture. The mixture type-reaction was determined by calculating the ratio $(R)$ between the observed mixture inhibitory ratio $(M I)$ and the sum of the inhibitory ratios of the mixture components as follows (Equation (3)):

$$
R=\frac{M I}{\sum_{n=1}^{i} I i}
$$

where $R$ represents the ratio between the observed mixture inhibitory ratio (MI) and the additive inhibitory ratios of the mixture components, $I i$ represents the inhibitory ratio of i-mixture components alone. $R=1$ indicates a sample additivity; $R<1$ and $R>1$ correspond to an antagonistic action and a synergistic action between the mixture components, respectively.

\section{Results and Discussion}

\subsection{Single Toxicity}

The power-time curves corresponding to the soil microbial activity in the con- 
trol sample and treated samples with different doses of $\mathrm{Cu}, \mathrm{PAX}$, and SIAX are shown in Figures 1(a)-(c). As it was reported in the previous similar studies, samples exhibited differences in the curves profiles and duration of the microbial growth phases (lag, exponential, stationary and death phases) indicating a dose-effect relationship [37] [38].

The lag and stationary phases were relatively extended in relation to the increase in the dose of pollutants. Different samples exhibited an interruption of the decline phase or death phase by reactivation and increase of the soil microbial growth, particularly for the samples treated with xanthates, individually or in the mixtures. Such a situation may be due to the growth of the surviving microbes that grow slowly (e.g. Fungi) [40] or take much time to adapt to pollutants. In addition, it is known that the first peak (Peak I) generally occurs at the exhaustion-time of glucose supplement [41]. Thus, the observed inflexion and secondary peaks (Peak II) can also be explained by the usage by the surviving organisms of secondary sources of metabolites, including through the decomposition of dead sensitive microbes, as well as the usage of the residual ammonium sulfate by some autotrophic microorganisms [37] [40].

The thermokinetic parameters and the corresponding statistics are presented in Table 1. The peak-time relatively increased with the increase in pollutants dose, but without a significant relationship (e.g. $14.88 \mathrm{~h}$ for the control sample, $16.2 \mathrm{~h}$ for $600 \mu \mathrm{g} \cdot \mathrm{Cu} \cdot \mathrm{g}^{-1}$ soil). The peak-power $\left(P_{\text {peak }}\right)$ significantly decreased $(P<$ 0.05 or $P<0.01$ ) in relation to the increase in pollutants dose (Table 1 and Table 2). The highest and lowest peak-power values were observed with the control sample $\left(1112.10 \mu \mathrm{W} \cdot \mathrm{g}^{-1}\right)$ and the highest dose of chemicals $(436.55,310.45$, and $264.13 \mu \mathrm{W} \cdot \mathrm{g}^{-1}$ for $200 \mu \mathrm{g} \cdot \mathrm{PAX} \cdot \mathrm{g}^{-1}$ soil, $200 \mu \mathrm{g} \cdot \mathrm{SIAX} \cdot \mathrm{g}^{-1}$ soil and $600 \mu \mathrm{g} \cdot \mathrm{Cu} \cdot \mathrm{g}^{-1}$ soil, respectively). For all treatments, the microbial growth rate constant $(K)$ significantly decreased with the pollutants dose. In contrast, the inhibitory ratio (I) significantly increased with the increasing treatment dose (Table 1 and Table 2). Based on the inhibitory ratio $(I)$ which is an ideal indicator of the toxicity effect [42], and the inhibitory concentrations (IC 12.5, IC 25 and IC 50) (Table 1), the highest and lowest toxicity were observed with SIAX and $\mathrm{Cu}$, respectively (e.g. IC 50 was $83.95 \mu \mathrm{g} \cdot \mathrm{g}^{-1}, 158.3 \mu \mathrm{g} \cdot \mathrm{g}^{-1}$, and $447.5 \mu \mathrm{g} \cdot \mathrm{g}^{-1}$ for SIAX, PAX and $\mathrm{Cu}$, respectively).

Different reasons may explain the observed lower toxicity level for copper than for xanthates.

In contrast to xanthates which are manmade organic chemicals recently produced, mainly for the mineral flotation purposes [13], $\mathrm{Cu}$ is naturally occurring in the environment. Therefore, soil microorganisms could have developed more homeostasis and resistance mechanisms along with their evolutionary pathway [43] [44] than it is for xanthates. Moreover, Cu plays an essential role of micronutrient for the living organisms. Specifically, $\mathrm{Cu}$ acts as a prosthetic group involved in a variety of metabolic pathways [24]. However, above a threshold concentration, $\mathrm{Cu}$ becomes harmful and negatively affects the microbial diversity, biomass, and functions [24] [45]. Such toxicological properties confer to $\mathrm{Cu}$ a 


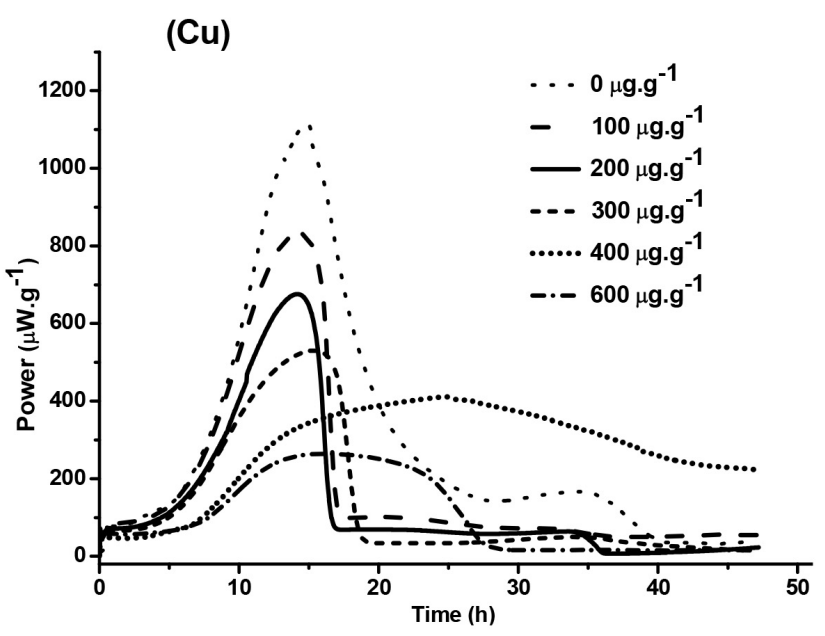

(a)

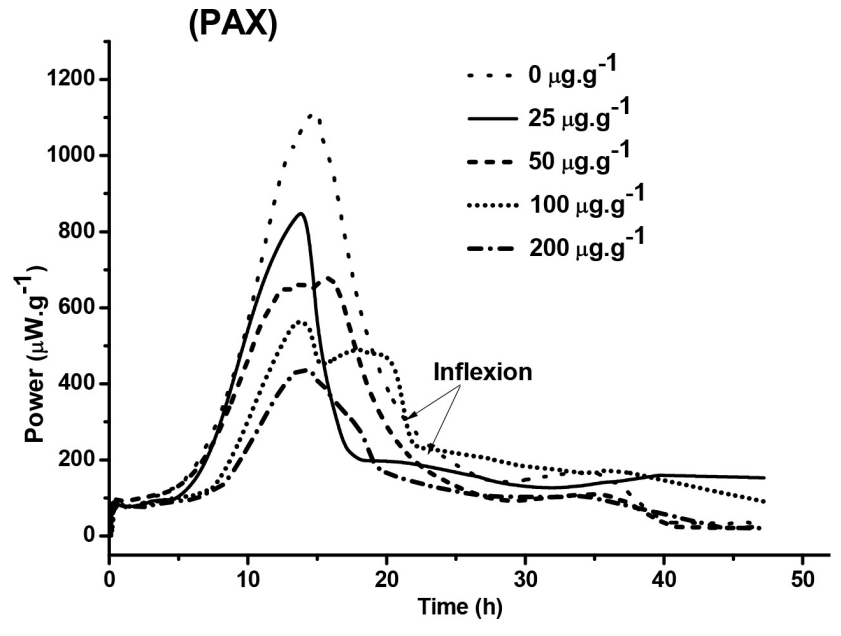

(b)

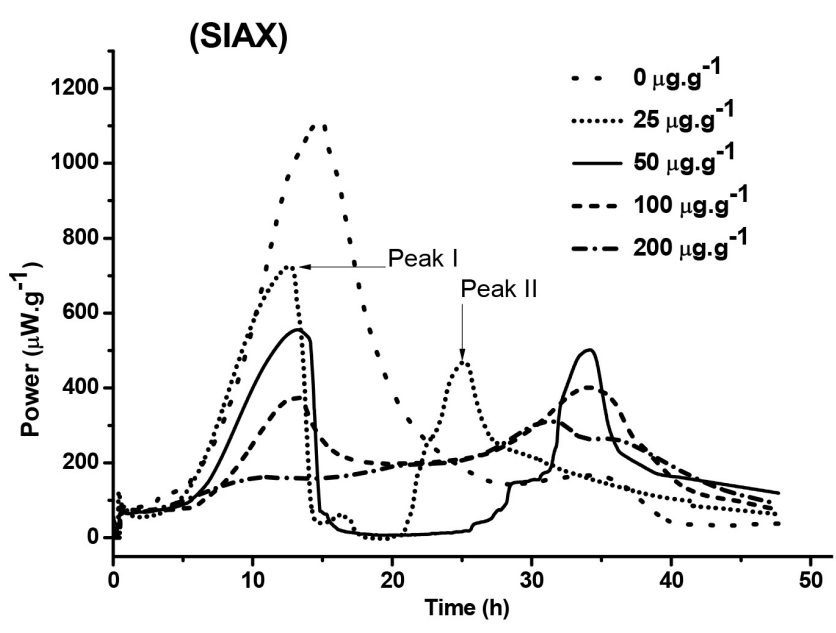

(c)

Figure 1. (a)-(c) Power-time curves of soil microbial metabolic activity as function of dose of copper (a), PAX (b) and SIAX (c).

wide range of use as a biocide and its application in medicine. With respect to xanthates, it was reported that even a very low dose, less than $1 \mathrm{mg} \cdot \mathrm{L}^{-1}$, is harmful to aquatic organisms [26]. From recent findings, xanthates, including sodium ethyl xanthate and sodium isobutyl xanthate, affected some moderately thermophilic, mineral-oxidizing acidophilic bacteria and mineral bioleaching bacteria (e.g. Leptospirillum sp., Acidimicrobium ferrooxidans, Acidithiobacillus caldus and Sulfobacillus sp.) and archaeon (e.g. Ferroplasma sp.), with a high sensitivity to less than $100 \mu \mathrm{g} \cdot \mathrm{mL}^{-1}$, and even to less than $1 \mu \mathrm{g} \cdot \mathrm{mL}^{-1}$ [46] [47] [48]. The activity of soil enzymes, including FDA hydrolyase and catalase (an antioxidative stress enzyme), was negatively affected by the exposure to sodium isobutyl xanthate and sodium isopropyl xanthate in the amounts ranging between 5 to $100 \mu \mathrm{g} \cdot \mathrm{g}^{-1}$ soil [49]. However, such a toxicity level can be influenced by the fate of xanthates and their decomposition products in the environment. In fact, unlike metals which are non-biodegradable and persistent elements, various organic compounds, including xanthates, are subject to various degradation 
Table 1. Soil microbial thermokinetic parameters under different doses of Copper $(\mathrm{Cu})$, potassium amyl xanthate (PAX) and sodium isoamyl xanthate (SIAX).

\begin{tabular}{|c|c|c|c|c|c|c|c|c|c|}
\hline Treatments & Dose $\left(\mu \mathrm{g} \cdot \mathrm{g}^{-1}\right)$ & $T_{\text {peak }}(\mathrm{h})$ & $P_{\text {peak }}\left(\mu \mathrm{W} \cdot \mathrm{g}^{-1}\right)$ & $P_{\text {peak }} \mathrm{r}(\%)$ & $K\left(\mathrm{~h}^{-1}\right)$ & $I(\%)$ & IC 12.5 & IC 25 & IC 50 \\
\hline control & 0 & 14.88 & 1113.10 & 100.00 & 0.26 & 0.00 & \multirow{7}{*}{106.25} & \multirow{7}{*}{220.00} & \multirow{7}{*}{447.5} \\
\hline \multirow{5}{*}{$\mathrm{Cu}$} & 100 & 14.28 & 832.23 & 74.77 & 0.23 & 11.54 & & & \\
\hline & 200 & 14.19 & 676.01 & 60.73 & 0.20 & 23.08 & & & \\
\hline & 300 & 15.31 & 530.52 & 47.66 & 0.17 & 34.62 & & & \\
\hline & 400 & 25.03 & 411.28 & 36.95 & 0.13 & 50.00 & & & \\
\hline & 600 & 16.17 & 264.13 & 23.73 & 0.09 & 65.38 & & & \\
\hline \multirow{4}{*}{ PAX } & 25 & 13.80 & 847.27 & 76.12 & 0.23 & 10.77 & & & \\
\hline & 50 & 15.75 & 677.34 & 60.85 & 0.20 & 23.08 & \multirow{3}{*}{28.05} & \multirow{3}{*}{54.15} & \multirow{3}{*}{158.3} \\
\hline & 100 & 13.79 & 563.09 & 50.59 & 0.16 & 38.46 & & & \\
\hline & 200 & 13.85 & 436.55 & 39.22 & 0.12 & 53.85 & & & \\
\hline \multirow{7}{*}{ SIAX } & 25 (Peak I) & 12.62 & 725.51 & 65.18 & 0.23 & 10.00 & \multirow{7}{*}{35.83} & \multirow{7}{*}{41.34} & \multirow{7}{*}{83.95} \\
\hline & (Peak II) & 25.18 & 467.72 & 42.02 & & & & & \\
\hline & 50 (Peak I) & 13.36 & 554.89 & 49.85 & 0.18 & 30.77 & & & \\
\hline & (Peak II) & 34.17 & 502.03 & 45.10 & & & & & \\
\hline & 100 (Peak I) & 13.04 & 372.75 & 33.49 & 0.11 & 57.69 & & & \\
\hline & (Peak II) & 34.15 & 401.84 & 36.10 & & & & & \\
\hline & 200 & 31.32 & 310.45 & 27.89 & 0.04 & 84.62 & & & \\
\hline
\end{tabular}

$T_{\text {peak }}=$ peak time; $P_{\text {peak }}=$ peak power; $K=$ microbial growth rate constant; $I=$ Inhibitory ration; $I C=$ Inhibitory concentration. In case of SIAX, the peak time and peak power are given for both first peak (Peak I) and second peak (Peak II) of the power time curves, respectively.

processes, the most important being the microbial-mediated decomposition [13] [31] [50]. Unfortunately, such chemicals decomposition does not always result in the detoxification of the affected system (production of less or non-toxic by-products), but can also lead to the formation of new toxic elements (equally or more adverse than those from which they originate) or nonbiodegradable or persistent compounds [51]. The moisture content and temperature, as well as the existence of potentially degrading microbial strains, of our experimental conditions are favorable for such xanthates decomposition. Xanthates decomposition leads to the generation of various toxic compounds, including carbon disulfide $\left(\mathrm{CS}_{2}\right)$, hydrogen sulfide $\left(\mathrm{H}_{2} \mathrm{~S}\right)$, hydrogen peroxide $\left(\mathrm{H}_{2} \mathrm{O}_{2}\right)$ [13] [31] [52] which can all affect the exposed microbial community. Human health-based studies have reported that $\mathrm{CS}_{2}$ was associated with a depletion of anti-oxidative defense mechanisms, with a decreased level of the plasma antioxidant $\alpha$-tocopherol and a decreased activity of antioxidant enzymes (i.e. glutathione peroxidase and catalase), the reduction in cytochrome P-450 and cytochrome c-reductase [53]. Exposure to $\mathrm{CS}_{2}$ resulted in clinical effects on male sexual function and semen quality [54]. Due to its toxicity to soil bacteria, $\mathrm{CS}_{2}$ is less biodegradable in soil and is used as soil disinfectant. Excessive $\mathrm{H}_{2} \mathrm{~S}$ is cytotoxic and lead to oxidative stress [55]. $\mathrm{H}_{2} \mathrm{~S}$ is harmful to the metal-containing enzymes 
Table 2. Correlation coefficients between the thermokinetic parameters of the soil microbes under single dose of $\mathrm{Cu}, \mathrm{PAX}$ and SIAX.

\begin{tabular}{|c|c|c|c|c|c|}
\hline & Dose & $T_{\text {peak }}$ & $P_{\text {peak }}$ & $K$ & $I$ \\
\hline \multicolumn{6}{|c|}{ Copper } \\
\hline Dose & 1 & & & & \\
\hline$T_{\text {peak }}$ & 0.431 & 1 & & & \\
\hline$P_{\text {peak }}$ & $-0.969^{* *}$ & -0.466 & 1 & & \\
\hline$K$ & $-0.995^{\star *}$ & -0.509 & $0.978^{* *}$ & 1 & \\
\hline$I$ & $0.995^{* *}$ & 0.509 & $-0.978^{\star *}$ & $-1.000^{* *}$ & 1 \\
\hline \multicolumn{6}{|c|}{ Potassium amyl xanthate } \\
\hline Dose & 1 & & & & \\
\hline$T_{\text {peak }}$ & -0.445 & 1 & & & \\
\hline$P_{\text {peak }}$ & $-0.890^{*}$ & 0.331 & 1 & & \\
\hline$K$ & $-0.969^{* *}$ & 0.400 & $0.966^{* *}$ & 1 & \\
\hline$I$ & $0.969^{\star *}$ & -0.400 & $-0.966^{\star \star}$ & $-1.000^{\star \star}$ & 1 \\
\hline \multicolumn{6}{|c|}{ Sodium isoamyl xanthate } \\
\hline Dose & 1 & & & & \\
\hline$T_{\text {peak }}$ & 0.851 & 1 & & & \\
\hline$P_{\text {peak }}$ & -0.839 & -0.450 & 1 & & \\
\hline$K$ & $-0.978^{* *}$ & -0.737 & $0.905^{*}$ & 1 & \\
\hline$I$ & $0.978^{\star *}$ & 0.737 & $-0.905^{\star}$ & $-1.000^{\star *}$ & 1 \\
\hline
\end{tabular}

[56] and can also interfere with Cytochrome c oxidase [57], inhibiting, therefore, the mitochondrial function or blocking the energy production. Such toxic effect was compared to that of cyanide and carbon monoxide [56]. The decomposition of $\mathrm{H}_{2} \mathrm{~S}$ is associated with the production of hydrogen peroxide and oxygen depletion (Equation (4)):

$$
\mathrm{O}_{2}+\mathrm{H}_{2} \mathrm{~S} \rightarrow \mathrm{S}^{\mathrm{o}}+\mathrm{H}_{2} \mathrm{O}_{2}
$$

$\mathrm{H}_{2} \mathrm{O}_{2}$ is an oxidative stress inducer and can lead to bacterial cell damage and death [58]. However, the high mobility of most of those xanthates decomposition products may affect their residence time and contact with the exposed organisms while it can lead to air and water pollution. For example, investigation have reported a high volatility and partition to air from soils and waters for $\mathrm{CS}_{2}$ [59], $\mathrm{H}_{2} \mathrm{~S}$ [59] [60] and COS [60]. Due to their low sorption capacity to soils and high water solubility, they are likely to be transported through moist soils and aquatic environment via water infiltration and reach the deep part of the Earth and the groundwater. In this study, despites the high inhibitory ratio or high toxic effect observed with SIAX, exposure to this chemical was generally characterized by a remarkable microbial growth after the first decline or death phase 
(Figure 1(c)). Such situation may be due to a rapid degradation or to a generation of less harmful degradation products than PAX. Based on this assumption, sodium isoamyl xanthate should be ecologically preferred to potassium amyl xanthates.

\subsection{Mixture Toxicity}

The power-time curves corresponding to microbial activity under the binary mixtures of the equitoxic doses of copper and xanthates, PAX and SIAX, are shown in Figure 2(a) and Figure 2(b). Those corresponding to the microbial exposure to the binary mixtures of a fixed dose of copper $\left(200 \mu \mathrm{g} \cdot \mathrm{g}^{-1}\right.$ soil $)$ and different xanthates doses $\left(25,50\right.$ and $100 \mu \mathrm{g} \cdot \mathrm{g}^{-1}$ soil) are shown in Figure 3(a) and Figure 3(b).

The corresponding thermokinetic parameters and the related statistical analysis are shown in Table 3. As for the single toxicity, the curves profiles exhibited lag, exponential, stationary and death phases of the microbial growth. The lag and stationary phases were relatively extended in relation to the increasing dose of the pollutants.

For all treated samples the peak-time $\left(T_{\text {peak }}\right)$ was higher than that of the control sample (Table 3) and was increased in relation to the applied dose. For the same dose of copper ( $200 \mu \mathrm{g} \cdot \mathrm{g}^{-1}$ soil), increasing the xanthates dose (from 25 to $100 \mu \mathrm{g} \cdot \mathrm{g}^{-1}$ soil) in the mixture was followed by a decrease in the peak-power $\left(P_{\text {peak }}\right)$ and microbial growth constant $(K)$. Conversely, the inhibitory ratio $(I)$ increased in the same treatment conditions.

For the same dose of copper $\left(200 \mu \mathrm{g} \cdot \mathrm{g}^{-1}\right.$ soil), increasing the xanthates dose (from 25 to $100 \mu \mathrm{g} \cdot \mathrm{g}^{-1}$ soil) in the mixture was followed by a decrease in the peak-power $\left(P_{\text {peak }}\right)$ and microbial growth constant $(K)$. Conversely, the inhibitory ratio $(I)$ increased in the same treatment conditions. For all cases, the observed mixture inhibitory ratio $(M I)$ was higher than that of the corresponding individual mixture components, meaning that the microbial communities are more affected by the simultaneous exposure to copper and xanthates than by the exposure to the single chemicals. For a mixture containing a copper dose of 200 $\mu \mathrm{g} \cdot \mathrm{g}^{-1}$ and a xanthates dose of $100 \mu \mathrm{g} \cdot \mathrm{g}^{-1}$, the corresponding inhibitory ratio was $53.85 \%$ compared to $38.5 \%$ for xanthates and $23.1 \%$ for copper. For example, in case of the mixture containing $200 \mu \mathrm{g} \cdot \mathrm{Cu} \cdot \mathrm{g}^{-1}$ and a xanthates dose of 25,50 and $100 \mu \mathrm{g} \cdot \mathrm{g}^{-1}$, the ratio (R) between the mixture inhibitory ratio and the sum of the individual components inhibitory ratios was less than 1 , corresponding to an antagonistic mixture-type reaction. However, with respect to the mixture of the equitoxic amounts, synergism was observed in soil treated with the lower chemicals doses $(R<1)$.

From these results, the microbial activity was not completely suppressed by any of the applied doses, including by the components whose sum of the individual inhibitory ratios equals $100 \%$ (Table 3 ). This may simply mean that copper and xanthates may have different sites of action and do not additive actions. In particular, it can be justified by the existence of some microbial strains that 


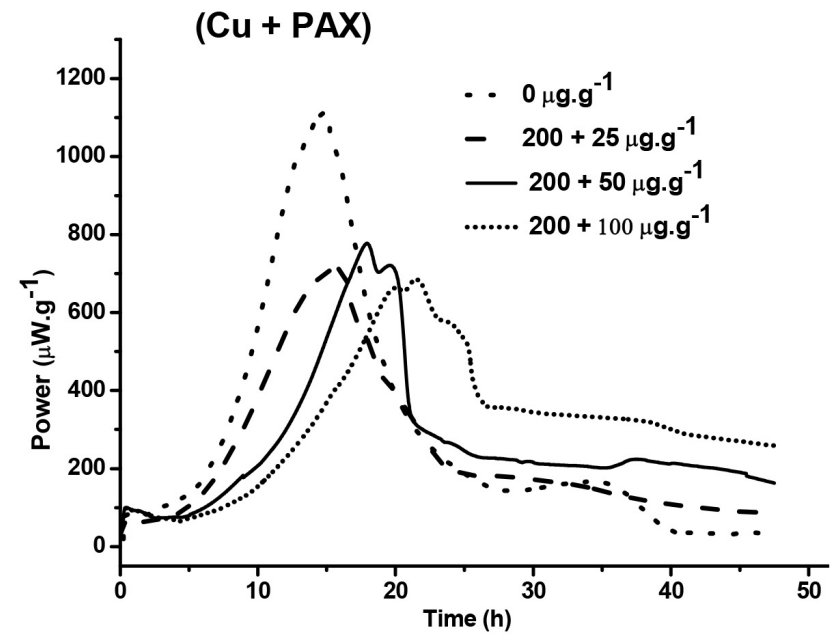

(a)

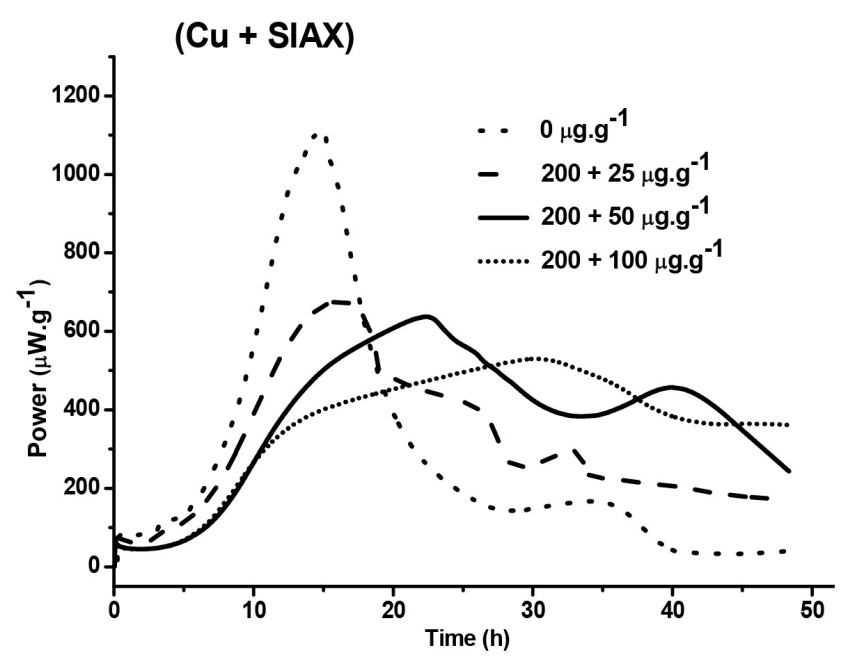

(b)

Figure 2. (a), (b) Power time curves of the microbial metabolic activity under the mixture of a fixed dose of copper $\left(200 \mu \mathrm{g} \cdot \mathrm{g}^{-1}\right)$ and different dose $\left(\mu \mathrm{g} \cdot \mathrm{g}^{-1}\right)$ of PAX (a) and SIAX (b).

$[C u+P A X(E Q)$.

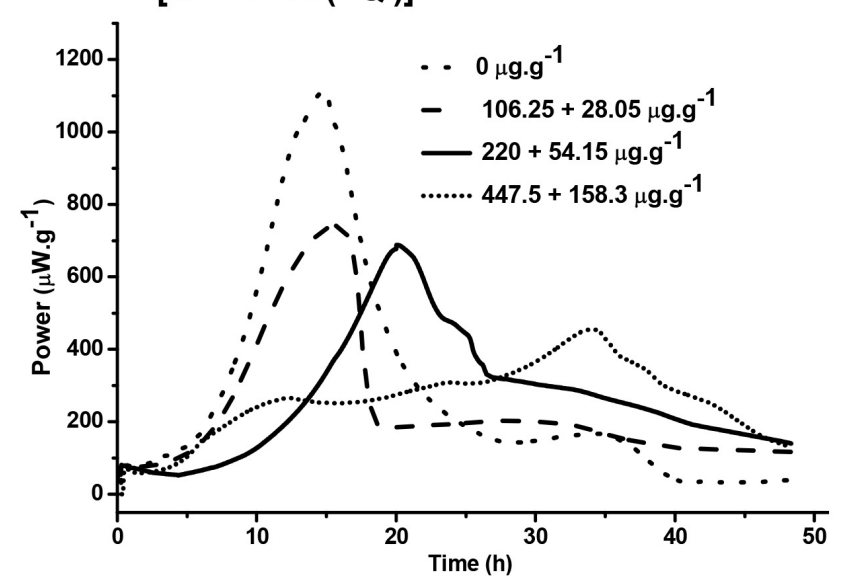

(a)

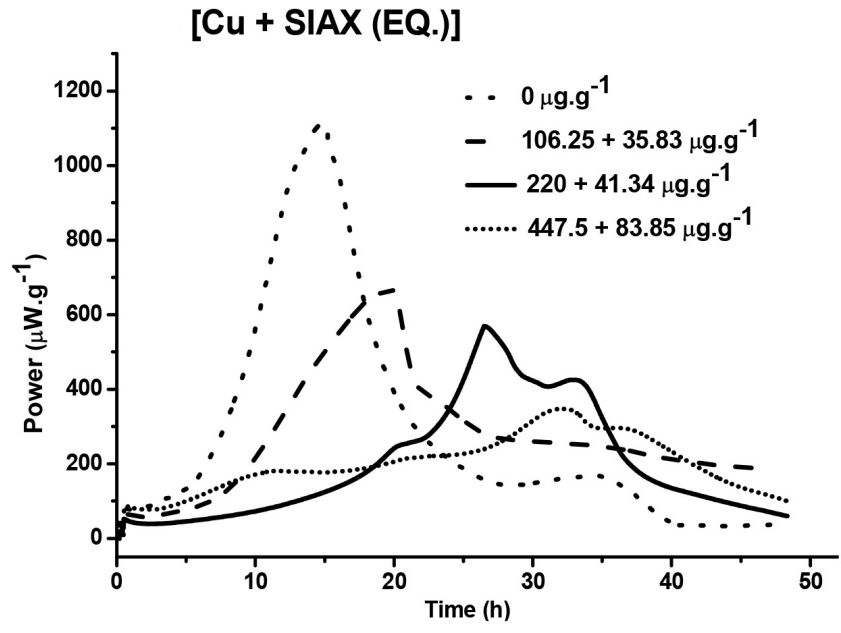

(b)

Figure 3. (a), (b) Power time curves of the soil microbial metabolic activity under the mixture of equitoxic doses of copper and PAX (a), and copper and SIAX (b). EQ. = equitoxic doses.

can adapt to all applied individual and combined chemicals doses, as well as to the formed complex copper/xanthates and to the xanthates associated decomposition products. It is well known that metals are mostly toxic in their free ionic form, mainly $\mathrm{Cu}^{2+}$ in case of copper, which can interact with the polar group $\left(\mathrm{S}=\mathrm{C}^{-} \mathrm{S}^{-}\right)$of xanthates [13] [61], reducing the interaction of both chemicals with microbes. Such affinity of xanthates for metals has some ecological implications. Xanthated materials are capable of sorption for the metal, as they are for other minerals [62] [63]. On this basis, Potassium ethyl xanthate was successfully tested for the treatment of copper-rich wastewater [64]. Depending on the chemicals species and doses, xanthates can negatively or positively affect the bacteria involved in the mineral bioleaching, including those belonging to the 
Table 3. Microbial thermokinetic parameters of the soil microbes exposed to mixture doses of copper and xanthates (PAX and SIAX).

\begin{tabular}{|c|c|c|c|c|c|c|c|c|c|c|c|c|}
\hline & & \multicolumn{4}{|c|}{ Mixtures components } & \multirow{3}{*}{$\begin{array}{l}\text { Peak-time } \\
\text { (h) }\end{array}$} & \multirow{3}{*}{$\begin{array}{c}\text { Peak-power } \\
\left(P_{\text {peak }}\right)\end{array}$} & \multirow{3}{*}{$K$} & \multirow{3}{*}{$\mathrm{AI}(\mathrm{Ia}+\mathrm{Ib})$} & \multirow{3}{*}{ Obs. MI } & \multirow{3}{*}{$\begin{array}{c}R \\
(M I / \mathrm{AI})\end{array}$} & \multirow{3}{*}{$\begin{array}{l}\text { Mixture-type } \\
\text { reaction }\end{array}$} \\
\hline & & \multicolumn{2}{|c|}{ Copper } & \multicolumn{2}{|c|}{ Xanthates } & & & & & & & \\
\hline & & $\begin{array}{c}\text { Dose } \\
\left(\mu \mathrm{g} \cdot \mathrm{g}^{-1}\right)\end{array}$ & Ia (\%) & $\begin{array}{c}\text { Dose } \\
\left(\mu \mathrm{g} \cdot \mathrm{g}^{-1}\right)\end{array}$ & Ib (\%) & & & & & & & \\
\hline \multirow{6}{*}{$\begin{array}{c}\text { Increased } \\
\text { xanthates } \\
\text { dose } \\
\text { in the } \\
\text { mixture }\end{array}$} & \multirow{3}{*}{$\mathrm{Cu}+\mathrm{PAX}$} & \multirow{6}{*}{200.00} & \multirow{6}{*}{23.07} & 25.00 & 10.77 & 15.75 & 711.68 & 0.20 & 33.85 & 23.08 & 0.68 & Antagonism \\
\hline & & & & 50.00 & 23.08 & 17.93 & 777.25 & 0.14 & 46.16 & 46.15 & 1.00 & Additivity \\
\hline & & & & 100.00 & 38.46 & 21.5 & 684.84 & 0.12 & 61.54 & 53.85 & 0.87 & Antagonism \\
\hline & \multirow{3}{*}{$\mathrm{Cu}+$ SIAX } & & & 25.00 & 10.00 & 16.20 & 675.88 & 0.19 & 33.08 & 26.92 & 0.81 & Antagonism \\
\hline & & & & 50.00 & 30.77 & 22.41 & 637.05 & 0.15 & 53.85 & 42.31 & 0.79 & Antagonism \\
\hline & & & & 100.00 & 57.70 & 30.22 & 530.23 & 0.11 & 80.77 & 57.69 & 0.71 & Antagonism \\
\hline \multirow{6}{*}{$\begin{array}{l}\text { Mixture of } \\
\text { equitoxic } \\
\mathrm{Cu} \text { and } \\
\text { xanthates } \\
\text { doses }\end{array}$} & \multirow{3}{*}{$\mathrm{Cu}+\mathrm{PAX}$} & 106.25 & 12.50 & 28.05 & 12.5 & 15.64 & 741.03 & 0.19 & 25.00 & 28.46 & 1.14 & Synergism \\
\hline & & 220.00 & 25.00 & 54.15 & 25.00 & 20.09 & 688.13 & 0.15 & 50.00 & 44.23 & 0.88 & Antagonism \\
\hline & & 447.50 & 50.00 & 158.3 & 50.00 & 33.95 & 454.16 & 0.05 & 100.00 & 81.92 & 0.82 & Antagonism \\
\hline & \multirow{3}{*}{$\mathrm{Cu}+$ SIAX } & 106.25 & 12.50 & 13.59 & 12.50 & 19.65 & 669.78 & 0.16 & 25.00 & 38.08 & 1.52 & Synergism \\
\hline & & 220.00 & 25.00 & 26.90 & 25.00 & 26.48 & 568.91 & 0.11 & 50.00 & 57.54 & 1.15 & Synergism \\
\hline & & 447.50 & 50.00 & 68.61 & 50.00 & 32.08 & 347.71 & 0.03 & 100.00 & 88.08 & 0.88 & Antagonism \\
\hline
\end{tabular}

Obs.MI = observed mixture inhibitory ratio; $\mathrm{AI}=$ additive inhibitory ratio; $K=$ microbial growth rate constant; $I=$ Inhibitory ratio; Ia = inhibitory ratio of copper alone; $\mathrm{Ib}=$ Inhibitory ratio of xanthates alone; $R=$ ratio between the observed mixture inhibitory ratio and the additive inhibitory ratio of the mixture components. For all cases, the observed mixture inhibitory ratio $(M I)$ is higher than the individual copper and xanthates inhibitory ratios.

family Thiobacteriaceae [65]. It should also be mentioned that xanthates degradation products have the ability to interact with other soil elements, including metals. $\mathrm{H}_{2} \mathrm{~S}$ has the ability to interact with heavy metals such as Nickel, Copper, Iron, and Zinc to form insoluble metal sulfides [60] while carbonyl sulfide is corrosive to metals [66]. Such interactions are likely to impacts on their availability and interactions with the exposed organisms. On this basis, it can be understood that the observed mixture toxicity effect in this study may result from different processes involving copper, xanthates and the xanthates decomposition products. Accordingly, the risk assessment and management of the pollution associated with metals, copper in this study, and xanthates should take into consideration this complexity of various elements.

\section{Conclusion}

The analysis of single and mixture toxicity of copper, potassium amyl xanthates and sodium amyl xanthates illustrated that all chemicals negatively affected the soil microbial activity. The highest and lowest inhibitory ratios were associated with SIAX and copper, respectively. Exposure to the binary mixtures of copper and potassium amyl xanthate or sodium amyl xanthate led to an increase in the toxicity level compared to individual chemicals. Increasing the xanthates doses (from 25 to $100 \mu \mathrm{g} \cdot \mathrm{g}^{-1}$ soil) in the mixture with a copper dose of $200 \mu \mathrm{g} \cdot \mathrm{g}^{-1}$ soil resulted in the increase of the mixture toxicity. Compared to additive individual 
chemical effects, exposure to a mixture of equitoxic amounts of copper and xanthates resulted either in synergistic mixture-type reaction or antagonistic mixture-type reaction. Therefore, in case of simultaneous application of copper and PAX or SIAX, and for the sustainability of the flotation process, optimizing the chemicals dose is still of a scientific and biotechnological challenge. This is not only interesting regarding the soil quality and function issues, but also for air and water quality issues that are influenced by the soil microbial mediated functions. Since the observed activity can be attributed to the activity of the resistant or less affected microbes, genetically based studies can allow a better understanding of the interactions between the soil microbial community and the chemicals mixture in presence. Resistance microbial strains can, therefore, be identified and can serve for the remediation of the pollution by copper and xanthates.

\section{Acknowledgements}

This study was supported by the Fundamental Research Funds for the Central Universities under the contract number FRF-OT-16-026.

\section{Conflicts of Interest}

Authors declare that there no potential conflict of interest associated with this work.

\section{References}

[1] Rong, X.-M., Huang, Q.-Y., Jiang, D.-H., Cai, P. and Liang, W. (2007) Isothermal Microcalorimetry: A Review of Applications in Soil and Environmental Sciences. Pedosphere, 17, 137-145. https://doi.org/10.1016/S1002-0160(07)60019-8

[2] Aislabie, J., Deslippe, J.R. and Dymond, J. (2013) Soil Microbes and Their Contribution to Soil Services. In: Dymond, J., Ed., Ecosystem Services in New Zealand: Conditions and Trends, Manaaki Whenua Press, Lincoln, 143-161.

[3] Gadd, G.M. (2010) Metals, Minerals and Microbes: Geomicrobiology and Bioremediation. Microbiology, 156, 609-643. https://doi.org/10.1099/mic.0.037143-0

[4] Gianfreda, L. and Rao, M.A. (2008) Interactions between Xenobiotics and Microbial and Enzymatic Soil Activity. Critical Reviews in Environmental Science and Technology, 38, 269-310. https://doi.org/10.1080/10643380701413526

[5] Dorsey, A. and Ingerman, L. (2004) Toxicological Profile for Copper.

[6] Luo, Y., Wu, L., Liu, L., Han, C. and Li, Z. (2009) Heavy Metal Contamination and Remediation in Asian Agricultural Land. Key Laboratory of Soil Environment and Pollution Remediation, Nanjing Institute of Soil Science.

[7] CCME (2007) Canadian Soil Quality Guidelines for the Protection of Environmental and Human Health: Summary Tables: Canada Council of Ministers of the Environment Winnipeg.

[8] Zhao, F.J., Ma, Y., Zhu, Y.G., Tang, Z. and McGrath, S.P. (2015) Soil Contamination in China: Current Status and Mitigation Strategies. Environmental Science \& Technology, 49, 750-759. https://doi.org/10.1021/es5047099 
[9] Health, U.D. and Services, H. (2004) Toxicological Profile for Copper. US Department of Health and Human Services, Atlanta.

[10] Reyes-Bozo, L., et al. (2014) Greening Chilean Copper Mining Operations through Industrial Ecology Strategies. Journal of Cleaner Production, 84, 671-679. https://doi.org/10.1016/j.jclepro.2014.03.088

[11] Li, N., et al. (2015) Highly Sensitive Determination of Butyl Xanthate in Surface and Drinking Water by Headspace Gas Chromatography with Electron Capture Detector. Chromatographia, 7, 1305-1310. https://doi.org/10.1007/s10337-015-2940-9

[12] Pearse J.M. (2005) An Overview of the Use of Chemical Reagents in Mineral Processing. Minerals Engineering, 18, 139-149. https://doi.org/10.1016/j.mineng.2004.09.015

[13] Bulatovic, S.M. (2007) Handbook of Flotation Reagents: Chemistry, Theory and Practice: Volume 1: Flotation of Sulfide Ores. Elsevier, New York.

[14] Rao, D., et al. (2009) Mineralogy and Geochemistry of a Low Grade Iron Ore Sample from Bellary-Hospet Sector, India and Their Implications on Beneficiation. Journal of Minerals \& Materials Characterization \& Engineering, 8, 115-131. https://doi.org/10.4236/jmmce.2009.82011

[15] Sicupira, L., Veloso, T., Reis, F. and Leão, V. (2011) Assessing Metal Recovery from Low-Grade Copper Ores Containing Fluoride. Hydrometallurgy, 109, 202-210. https://doi.org/10.1016/j.hydromet.2011.07.003

[16] Nicnas, S.E.X. (2000) Priority Existing Chemical. Secondary Notification Assessment, Report N5S, 20-22.

[17] Edraki, M., et al. (2014) Designing Mine Tailings for Better Environmental, Social and Economic Outcomes: A Review of Alternative Approaches. Journal of Cleaner Production, 84, 411-420. https://doi.org/10.1016/j.jclepro.2014.04.079

[18] Dixit, R., et al. (2015) Bioremediation of Heavy Metals from Soil and Aquatic Environment: An Overview of Principles and Criteria of Fundamental Processes. Sustainability, 7, 2189-2212. https://doi.org/10.3390/su7022189

[19] Antoniadis, V., et al. (2017) Bioavailability and Risk Assessment of Potentially Toxic Elements in Garden Edible Vegetables and Soils around a Highly Contaminated Former Mining Area in Germany. Journal of Environmental Management, 186, 192-200. https://doi.org/10.1016/j.jenvman.2016.04.036

[20] Azam, S. and Li, Q. (2010) Tailings Dam Failures: A Review of the Last One Hundred Years. Geotechnical News, 28, 50-54.

[21] Rico, M., Benito, G., Salgueiro, A.R., Díez-Herrero, A. and Pereira, H.G. (2008) Reported Tailings Dam Failures: A Review of the European Incidents in the Worldwide Context. Journal of Hazardous Materials, 152, 846-852. https://doi.org/10.1016/j.jhazmat.2007.07.050

[22] Xie, X.H., et al. (2012) Heavy Metal Resistance by Two Bacteria Strains Isolated from a Copper Mine Tailing in China. African Journal of Biotechnology, 9, 4056-4066.

[23] Hobman, J.L. and Crossman, L.C. (2015) Bacterial Antimicrobial Metal Ion Resistance. Journal of Medical Microbiology, 64, 471-497. https://doi.org/10.1099/jmm.0.023036-0

[24] Li, J., et al. (2014) Initial Copper Stress Strengthens the Resistance of Soil Microorganisms to a Subsequent Copper Stress. Microbial Ecology, 67, 931-941. https://doi.org/10.1007/s00248-014-0391-8

[25] Yanev, S.G., et al. (2000) Mechanistic Studies of Cytochrome P450 2B1 Inactivation 
by Xanthates. Archives of Biochemistry and Biophysics, 378, 157-166.

https://doi.org/10.1006/abbi.2000.1807

[26] Rostad, C.E., Schmitt, C.J., Schumacher, J.G. and Leiker, T.J. (2011) An Exploratory Investigation of Polar Organic Compounds in Waters from a Lead-Zinc Mine and Mill Complex. Water, Air, \& Soil Pollution, 217, 431-443.

https://doi.org/10.1007/s11270-010-0598-3

[27] Hertzberg, R.C. and MacDonell, M.M. (2002) Synergy and Other Ineffective Mixture Risk Definitions. Science of the Total Environment, 288, 31-42. https://doi.org/10.1016/S0048-9697(01)01113-5

[28] Chen, H., et al. (2010) Toxicity of Three Phenolic Compounds and Their Mixtures on the Gram-Positive Bacteria Bacillus subtilis in the Aquatic Environment. Science of the Total Environment, 408, 1043-1049.

https://doi.org/10.1016/j.scitotenv.2009.11.051

[29] Cedergreen, N., et al. (2008) A Review of Independent Action Compared to Concentration Addition as Reference Models for Mixtures of Compounds with Different Molecular Target Sites. Environmental Toxicology and Chemistry, 27, 1621-1632. https://doi.org/10.1897/07-474.1

[30] Altenburger, R., et al. (2000) Predictability of the Toxicity of Multiple Chemical Mixtures to Vibrio fischeri: Mixtures Composed of Similarly Acting Chemicals. Environmental Toxicology and Chemistry, 19, 2341-2347. https://doi.org/10.1002/etc.5620190926

[31] Molina, G.C., Bonkat, G., Wirz, D. and Bachmann, A. (2013) Sodium Isopropyl Xanthate Degradation by Advanced Oxidation Processes. Minerals Engineering, 45, 88-93. https://doi.org/10.1016/j.mineng.2012.12.001

[32] Braissant, O., Wirz, D., Gopfert, B. and Daniels, A.U. (2013) Microbial Growth and Isothermal Microcalorimetry: Growth Models and Their Application to Microcalorimetric Data. Thermochimica Acta, 555, 64-71. https://doi.org/10.1016/j.tca.2012.12.005

[33] Braissant, O., et al. (2010) Biomedical Use of Isothermal Microcalorimeters. Sensors, 10, 9369-9383. https://doi.org/10.3390/s101009369

[34] Bravo, D., et al. (2011), Use of an Isothermal Microcalorimetry Assay to Characterize Microbial Oxalotrophic Activity. FEMS Microbiology Ecology, 78, 266-274. https://doi.org/10.1111/j.1574-6941.2011.01158.x

[35] Fierer, N., Schimel, J.P. and Holden, P.A. (2003) Variations in Microbial Community Composition through Two Soil Depth Profiles. Soil Biology and Biochemistry, 35, 167-176. https://doi.org/10.1016/S0038-0717(02)00251-1

[36] Guo, Z., et al. (2016) Effect of Three Typical Sulfide Mineral Flotation Collectors on Soil Microbial Activity. Environmental Science and Pollution Research, 23, 7425-7436. https://doi.org/10.1007/s11356-015-5899-Z

[37] Chen, H., et al. (2014) Short-Term Effect of Aniline on Soil Microbial Activity: A Combined Study by Isothermal Microcalorimetry, Glucose Analysis, and Enzyme Assay Techniques. Environmental Science and Pollution Research, 21, 674-683. https://doi.org/10.1007/s11356-013-1955-8

[38] Wang, F., et al. (2010) Short-Time Effect of Heavy Metals upon Microbial Community Activity. Journal of Hazardous Materials, 173, 510-516. https://doi.org/10.1016/j.jhazmat.2009.08.114

[39] Núñez-Regueira, L., Rodríguez-Añón, J.A. and Proupín-Castiñeras, J. and NúñezFernàndez, O. (2006) Microcalorimetric Study of Changes in the Microbial Activity 
in a Humic Cambisol after Reforestation with Eucalyptus in Galicia (NW Spain). Soil Biology \& Biochemistry, 38, 115-124. https://doi.org/10.1016/j.soilbio.2005.04.031

[40] Barros, N., Feijóo, S., Fernández, S., Simoni, J. and Airoldi, C. (2000) Application of the Metabolic Enthalpy Change in Studies of Soil Microbial Activity. Thermochimica Acta, 356, 1-7. https://doi.org/10.1016/S0040-6031(00)00495-0

[41] Barja, I. and Núñez, L. (1999) Microcalorimetric Measurements of the Influence of Glucose Concentration on Microbial Activity in Soils. Soil Biology \& Biochemistry, 31, 441-447. https://doi.org/10.1016/S0038-0717(98)00149-7

[42] Zhu, X., et al. (2018) Combined Effects of Antimony and Sodium Diethyldithiocarbamate on Soil Microbial Activity and Speciation Change of Heavy Metals. Implications for Contaminated Lands Hazardous Material Pollution in Nonferrous Metal Mining Areas. Journal of Hazardous Materials, 349, 160-167. https://doi.org/10.1016/j.jhazmat.2018.01.044

[43] Cervantes, C. and Gutierrez-Corona, F. (1994) Copper Resistance Mechanisms in Bacteria and Fungi. FEMS Microbiology Reviews, 14, 121-137. https://doi.org/10.1111/j.1574-6976.1994.tb00083.x

[44] Hobman, J.L. and Crossman, L.C. (2015), Bacterial Antimicrobial Metal ion Resistance. Journal of Medical Microbiology, 64, 471-497. https://doi.org/10.1099/jmm.0.023036-0

[45] Ahemad, M. (2012) Implications of Bacterial Resistance against Heavy Metals in Bioremediation: A Review. Journal of Institute of Integrative Omics and Applied Biotechnology, 3, 39-46.

[46] Okibe, N. and Johnson, D.B. (2002) Toxicity of Flotation Reagents to Moderately Thermophilic Bioleaching Microorganisms. Biotechnology Letters, 24, 2011-2016. https://doi.org/10.1023/A:1021118915720

[47] Dong, Y. and Hai, L. (2012) Influences of Flotation Reagents on Bioleaching of Chalcopyrite by Acidthiobacillus ferrooxidans. Minerals Engineering, 32, 27-29. https://doi.org/10.1016/j.mineng.2012.03.007

[48] Jafari, M., et al. (2016) A Comparative Study on the Effect of Flotation Reagents on Growth and Iron Oxidation Activities of Leptospirillum ferrooxidans and Acidithiobacillus ferrooxidans. Minerals, 7, 2. https://doi.org/10.3390/min7010002

[49] Bararunyeretse, P., et al. (2017) Toxic Effect of Two Kinds of Mineral Collectors on Soil Microbial Richness and Activity: Analysis by Microcalorimetry, Microbial Count, and Enzyme Activity Assay. Environmental Science and Pollution Research, 24, 1565-1577. https://doi.org/10.1007/s11356-016-7905-5

[50] Chen, S., et al. (2011) Primary Biodegradation of Sulfide Mineral Flotation Collectors. Minerals Engineering, 24, 953-955. https://doi.org/10.1016/j.mineng.2011.01.003

[51] Fetzner, S. (2002) Biodegradation of Xenobiotics. Department of Microbiology, University of Oldenburg, Oldenburg.

[52] Sun, Z. and Forsling, W. (1997) The Degradation Kinetics of Ethyl-Xanthate as a Function of pH in Aqueous Solution. Minerals Engineering, 10, 389-400. https://doi.org/10.1016/S0892-6875(97)00016-2

[53] ATSDR (1996) Toxicological Profile for Carbon Disulfide (Update). US Department of Health and Human Services, Public Health Service, Agency for Toxic Substances and Disease Registry, Atlanta, 219 p.

[54] Ma, J.-Y., et al. (2010) The Effects of Carbon Disulfide on Male Sexual Function and Semen Quality. Toxicology and Industrial Health, 26, 375-382. 
https://doi.org/10.1177/0748233710369127

[55] Greabu, M., et al. (2016) Hydrogen Sulfide, Oxidative Stress and Periodontal Diseases: A Concise Review. Antioxidants, 5, 3. https://doi.org/10.3390/antiox5010003

[56] Bagarinao, T. (1992) Sulfide as an Environmental Factor and Toxicant: Tolerance and Adaptations in Aquatic Organisms. Aquatic Toxicology, 24, 21-62. https://doi.org/10.1016/0166-445X(92)90015-F

[57] Khan, A., et al. (1990) Effects of Hydrogen Sulfide Exposure on Lung Mitochondrial Respiratory Chain Enzymes in Rats. Toxicology and Applied Pharmacology, 103, 482-490. https://doi.org/10.1016/0041-008X(90)90321-K

[58] Jennings, M.E., et al. (2014) Expression of a Bacterial Catalase in a Strictly Anaerobic Methanogen Significantly Increases Tolerance to Hydrogen Peroxide but Not Oxygen. Microbiology, 160, 270-278. https://doi.org/10.1099/mic.0.070763-0

[59] Cox, S.F., McKinley, J.D., Ferguson A.S., O’Sullivan, G. and Kalin, R (2013) Degradation of Carbon Disulphide $\left(\mathrm{CS}_{2}\right)$ in Soils and Groundwater from a $\mathrm{CS}_{2}$-Contaminated Site. Environmental Earth Sciences, 68, 1935-1944.

https://doi.org/10.1007/s12665-012-1881-y

[60] ATSDR (2016) Toxicological Profile for Hydrogen Sulfide and Carbonyl Sulfide. US Department of Health and Human Services Public Health Service, Agency for Toxic Substances and Disease Registry, 298 p.

[61] Fu, P., Feng, J., Yang, T. and Yang, H. (2015) Comparison of Alkyl Xanthates Degradation in Aqueous Solution by the $\mathrm{O}_{3}$ and $\mathrm{UV} \mathrm{O}_{3}$ Processes: Efficiency, Mineralization and Ozone Utilization. Minerals Engineering, 81, 128-134. https://doi.org/10.1016/j.mineng.2015.08.001

[62] Babel, S. and Kurniawan, T.A. (2003) Low-Cost Adsorbents for Heavy Metals Uptake from Contaminated Water: A Review. Journal of Hazardous Materials, 97, 219-243. https://doi.org/10.1016/S0304-3894(02)00263-7

[63] Lakherwal, D. (2014) Adsorption of Heavy Metals: A Review. International Journal of Environmental Research and Development, 4, 41-48.

[64] Arbabi, M. and Golshani, N. (2016) Removal of Copper Ions Cu(II) from Industrial Wastewater. International Journal of Epidemiologic Research, 3, 283-293.

[65] Seifelnassr, A.A.S. and Abouzeid, A.-Z.M. (2013) Exploitation of Bacterial Activities in Mineral Industry and Environmental Preservation: An Overview. Journal of Mining, 2013, Article ID: 507168. https://doi.org/10.1155/2013/507168

[66] Bank, H.H.S.D. (2007) National Library of Medicine, Bethesda. 